Article

\title{
Outbreak of Phoracantha semipunctata in Response to Severe Drought in a Mediterranean Eucalyptus Forest
}

\author{
Stephen Seaton ${ }^{1, *}$, George Matusick ${ }^{1,2, \dagger}$, Katinka X. Ruthrof ${ }^{1, \dagger}$ and Giles E. St. J. Hardy ${ }^{1, \dagger}$ \\ 1 Centre of Excellence for Climate Change Woodland and Forest Health, School of Veterinary and \\ Life Sciences, Murdoch University, Murdoch, Western Australia 6150, Australia; \\ E-Mails: g.matusick@murdoch.edu.au (G.M.); k.ruthrof@murdoch.edu.au (K.X.R.); \\ g.hardy@murdoch.edu.au (G.E.S.J.H.) \\ 2 The Nature Conservancy, Georgia Chapter, Chattahoochee Fall Line Conservation Office, \\ Fort Benning, GA 31905, USA \\ $\dagger$ These authors contributed equally to this work. \\ * Author to whom correspondence should be addressed; E-Mail: s.seaton@ murdoch.edu.au; \\ Tel.: +61-893-606-272; Fax: +61-893-606-303.
}

Academic Editor: Diana F. Tomback

Received: 29 August 2015 / Accepted: 27 October 2015 / Published: 30 October 2015

\begin{abstract}
Extreme climatic events, including droughts and heatwaves, can trigger outbreaks of woodboring beetles by compromising host defenses and creating habitat conducive for beetle development. As the frequency, intensity, and duration of droughts are likely to increase in the future, beetle outbreaks are expected to become more common. The combination of drought and beetle outbreaks has the potential to alter ecosystem structure, composition, and function. Our aim was to investigate a potential outbreak of the native Eucalyptus longhorned borer, Phoracantha semipunctata ( $P$. semipunctata), following one of the most severe droughts on record in the Northern Jarrah Forest of Southwestern Australia. Beetle damage and tissue moisture were examined in trees ranging from healthy to recently killed. Additionally, beetle population levels were examined in adjacent forest areas exhibiting severe and minimal canopy dieback. Severely drought-affected forest was associated with an unprecedented outbreak of $P$. semipunctata, with densities 80 times higher than those observed in surrounding healthier forest. Trees recently killed by drought had significantly lower tissue moisture and higher feeding damage and infestation levels than those trees considered healthy or in the process of
\end{abstract}


dying. These results confirm the outbreak potential of $P$. semipunctata in its native Mediterranean-climate Eucalyptus forest under severe water stress, and indicate that continued drying will increase the likelihood of outbreaks.

Keywords: woodborer; damage; die-off; die-back; forest mortality; heat wave; Cerambycidae; populations; climate change; Jarrah

\section{Introduction}

Woodboring beetles are among the most widespread insect pests of trees, and can be especially responsive to drought stress in their hosts [1-3]. With droughts expected to increase with climate change in many regions [4], outbreaks of some woodboring beetles are expected to become more frequent and intense [5]. For example, forests in Mediterranean regions are already experiencing significant shifts in precipitation and temperatures, increasing tree water stress [6-8]. Associated with these climate changes, forests are being challenged from abiotic factors (e.g. high temperatures and drought) and by biotic factors such as damaging outbreaks of woodboring beetles in semiarid, temperate, and boreal climate regions [9-12]. While bark beetles (Coleoptera: Curculionidae) are well-known forest pests of drought-stressed hosts, other woodboring beetles (e.g., Cerambycidae and Buprestidae) can also cause widespread damage under drought conditions [13]. For example, in the Ozark mountains (a temperate climate region) of the Southeastern United States, outbreaks of the red oak borer (Enaphalodes rufulus Haldeman (E. rufulus) (Coleoptera: Cerambycidae)), coinciding with drought and loss of tree vigor, led to large-scale mortality of several Quercus species in the early 2000s [13].

Phoracantha semipunctata (P. semipunctata) (Coleoptera: Cerambycidae) has become a major pest of Eucalyptus species throughout the world where they have been introduced [14,15]. Worldwide, it is among the most economically damaging Phoracantha species [15]. For example, in California, it causes extensive tree losses, attacking a wide range of Eucalyptus species in plantations [16,17]. Drought stress is a predisposing factor for P. semipunctata attack and tree mortality [15]. Despite the amount of literature on this species outside of Australia, in its native forest ecosystems in drought prone Australia, where the insect has a wide distribution [18], its behavior and response to drought stress in its hosts has received limited attention. In fact, evidence of $P$. semipunctata causing widespread damage to its native ecosystems is rare $[19,20]$.

The Mediterranean climate region of Southwestern Australia has experienced a climatic shift since the 1970s, with a step-wise reduction in rainfall and steady increase in average temperature [5]. Coinciding with this drying trend, a series of canopy dieback events have occurred in multiple ecosystems over the past two decades [21,22], with some associated with outbreaks of endemic woodboring beetles [23]. The largest, in terms of spatial extent, and most damaging event, occurred during the Australian summer 2010/2011 in the largest forest type in the region (the Northern Jarrah Forest) [24]. While dieback and tree mortality were largely suspected to be driven by the combination of drought and heat, woodboring beetle activity was also evident in many dying and recently-killed trees [24]. Collection of adults from infested stems showed that the native $P$. semipunctata was the 
primary beetle present in the two overstory dominant tree species in the Northern Jarrah Forest, Eucalyptus marginata Donn ex Smith (E. marginata) and Corymbia calophylla L.A.S Johnson (C. calophylla) (Matusick, pers. observations). Although the behavior of P. semipunctata is well known where it has been introduced outside of Australia [15,16,25], little research has been conducted on its population biology and host damage in native ecosystems. Furthermore, given the close association of $P$. semipunctata with tree water stress, and the magnitude of climate changes projected for the Australian continent, research on this species is particularly important.

Following the cessation of drought in 2011, we conducted a study to determine the host damage and infestation response of $P$. semipunctata in relation to drought stress in the Northern Jarrah Forest of Southwestern Australia. Two surveys were conducted (2011 and 2012) to determine (1) the association between tree crown health and damage by P. semipunctata (2011), and (2) the infestation of $P$. semipunctata in severely and minimally drought-affected forest areas and among trees of varying health conditions (2012). Results will determine the strength of the association between $P$. semipunctata and severe host drought stress, and provide a basis to estimate its outbreak potential with continued drying in the region.

\section{Experimental Section}

\subsection{Study Area}

The Northern Jarrah Forest ranges from tall open sclerophyll forest in the west to open woodland in the east due to a strong west-east precipitation (ranging from $1300 \mathrm{~mm}$ to $800 \mathrm{~mm}$ ) and evaporation gradient (ranging from $575 \mathrm{~mm}$ to $700 \mathrm{~mm}$ ) [26]. The uplands are dominated by E. marginata and C. calophylla, which commonly occur as overstory codominants. Common midstory species include Allocasuarina fraseriana (Miq.) L.A.S.Johnson, Banksia grandis Wild, Persoonia longifolia R.Br, and Persoonia elliptica R.Br [27]. Soils throughout the study area are lateritic, predominantly ironstone gravels with sandy matrixes of low moisture holding capacity, and include many areas of shallow soils over granite [28].

\subsection{Study Site and Plot Selection}

Twenty sites were selected for field sampling from a population of 235 severely drought-affected sites determined by an aerial survey in May 2011 (Figure 1). For detailed methods of the aerial survey see Matusick et al. [24]. Briefly, the severely-affected sites (>70\% complete crown discoloration) were located from the aerial survey and accurately delineated using a differential GPS (Pathfinder Pro XRS receiver, Trimble Navigation Ltd., Sunnyvale, CA, USA) $( \pm 0.4 \mathrm{~m})$ on the ground.

In June 2011, shortly following the cessation of drought, a survey was conducted to estimate beetle damage to trees. Plots were selected by choosing 3 points randomly on a $20 \mathrm{~m} \times 20 \mathrm{~m}$ grid (using fGIS forestry cruise software (Wisconsin DNR-Division of Forestry, Madison, United States) from within the severely-affected forest in each of the 20 sites selected and represented the center point of a 0.011 ha fixed radius forest plot. Severely-affected areas were associated with shallow soils surrounding rock outcrops and on soil types with lower water holding capacity than minimally-affected areas [29]. Additionally, 3 plots were located outside the severely-affected area in forest minimally-affected 
( $<20 \%$ crown discoloration). These plots were located $20 \mathrm{~m}$ outside the perimeter of the severely-affected area. A differential GPS was used to locate plots within each area.

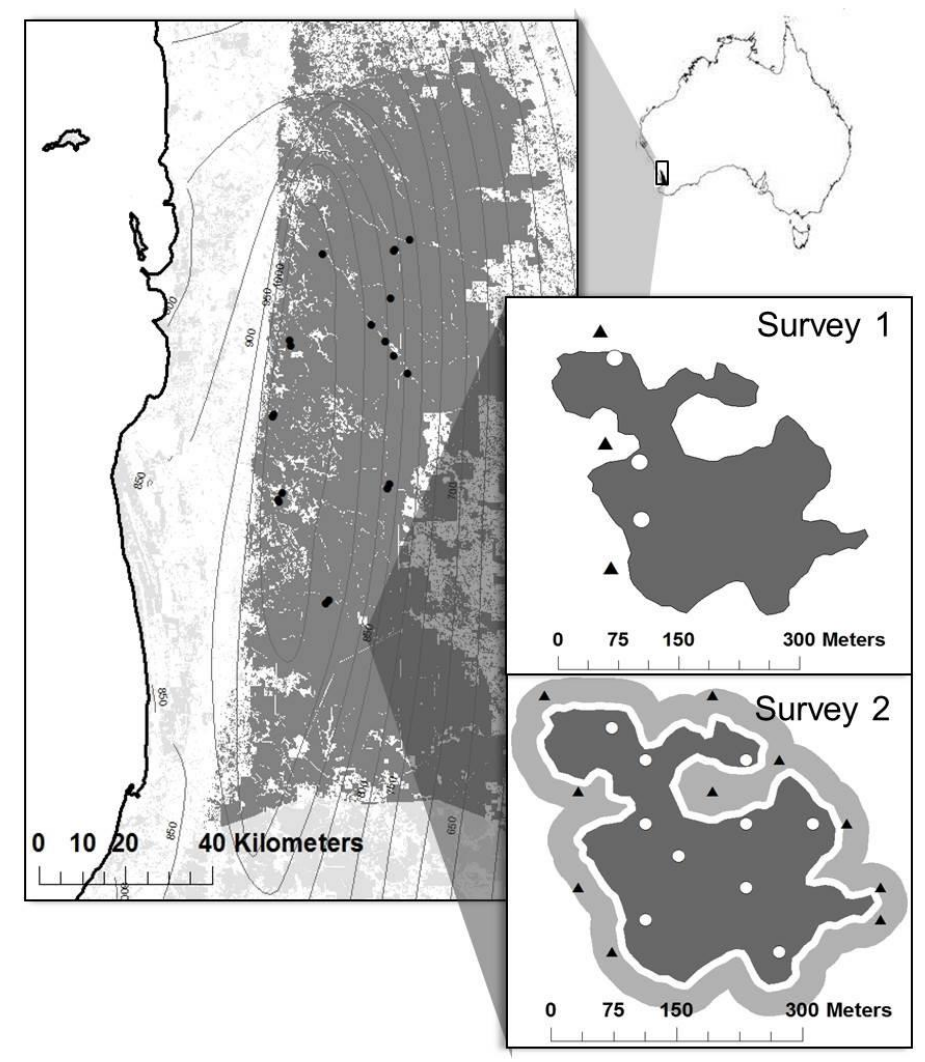

Figure 1. Study site location was the Northern Jarrah Forest of Southwestern Australia. Study sites (black dots) were located in the remaining intact, native vegetation of the forest (dark grey color). Within each study site (inset), three and ten plot locations were randomly selected for severely- (white dots) and minimally-affected (black triangles) forest area for Survey 1 and Survey 2, respectively. The discrete nature of the damage allowed for sampling both severely and minimally drought-affected forest in close proximity. A $10 \mathrm{~m}$ forest area buffered severely from minimally-affected areas.

For the second survey in May 2012, a subset of 11 sites was revisited to estimate beetle infestation levels. The life cycle of $P$. semipunctata is known to last up to 9 months [30], so by returning to the sites after this time it ensured nearly all $P$. semipunctata had emerged from infested trees. For this survey, the minimally-affected forest areas were defined as a band of forest $30 \mathrm{~m}$ wide surrounding the severely-affected area, buffered by $10 \mathrm{~m}$ from the severely-affected area (Figure 1). The distinct and sharp contrast between severely and minimally drought-affected areas allowed for sampling of both populations in close proximity to one another. Twenty plot point locations were chosen randomly on a $40 \mathrm{~m} \times 40 \mathrm{~m}$ grid using fGIS within severely and minimally drought-affected forest, and a subset of 6-10 points were used for sampling. On each plot point, the point-centered quarter method of tree sampling was used to select trees [31]. Four trees were selected surrounding each point by measuring the closest tree (E. marginata or C. calophylla, diameter at breast height over bark (DBHOB) $>10 \mathrm{~cm}$ ) to the plot point in each of four quadrats (NW, NE, SE, SW). The distance from the plot center to the 
four trees selected was measured and used to determine the density of trees in each forest area based on the methods outlined in Mitchell [31].

\subsection{Damage and Tissue Moisture}

Either 3 or 4 overstory trees (>10 cm DBHOB, E. marginata or C. calophylla) were chosen for sampling on each plot. Each sampled tree was assessed using differences in visual condition [32] and placed into one of three crown health classes, based on the severity of discoloration exhibited by crown foliage, adapted from Worrall et al. [33]. Trees considered "healthy" had predominantly (>75\%) green, turgid foliage and limited evidence of stress, "dying" trees had predominantly yellow, pink, and/or dry foliage, while "recently killed" trees had completely red, dead foliage. On each tree at DBHOB and ground line, four patches of bark, greater than $100 \mathrm{~cm}^{2}$ in size, were removed from each cardinal direction (8-100 $\mathrm{cm}^{2}$ patches per tree). Removing the bark exposed the surface of the inner bark/phloem where $P$. semipunctata forms feeding galleries [16]. The area of stem surface damaged by $P$. semipunctata feeding was determined to the nearest $1 \mathrm{~cm}^{2}$ using a $100 \mathrm{~cm}^{2}$ transparent grid, placed over each patch of exposed inner bark. In order to estimate the phloem and outer sapwood tissue moisture, which is thought to be important in $P$. semipunctata infestation success [14,34], a $2 \mathrm{~cm}$ diameter plug of tissue was collected from each sampled patch using a $19 \mathrm{~mm}$ diameter drill bit. Tissue samples were weighed in the field immediately following collection, taken to the laboratory, dried at $70{ }^{\circ} \mathrm{C}$ for five days, and re-measured to determine moisture content.

\subsection{Infestation Levels}

For each tree, the loose outer bark was scraped from the bottom $2 \mathrm{~m}$ of the stem to more clearly detect $P$. semipunctata exit holes. Following outer bark removal, the total number of $P$. semipunctata exit holes (defined as being $8-12 \mathrm{~mm}$ in diameter) was counted. The density of $P$. semipunctata (exit holes per $\mathrm{m}^{2}$ stem surface area) was derived for each tree using DBHOB and assuming a perfect cylinder of $2 \mathrm{~m}$ in height. These methods closely followed other studies, where Cerambycid beetle populations were estimated using only the bottom $2 \mathrm{~m}$ of trees [35], and is justified by within-tree studies that have shown this area represents the majority of beetle emergence [36] Seaton (unpublished data). To calculate adult emergence $\left(\mathrm{ha}^{-1}\right)$ tree densities found from surveys, and population levels per tree for each forest area (averaged over all sites measured) were then scaled-up and used to calculate total estimated borer populations for each minimally and severely drought-affected forest areas. Sample trees crown health were similarly assigned into classes based on Worrall et al. [33], where; "healthy" showed limited evidence of crown dieback from the disturbance (>90\% of original crown present), "moderate dieback" included trees showing evidence of partial crown dieback, while retaining some (>10\%) original foliage, "severe dieback" included trees which lost all original foliage (and had coppice and epicormic shoots present) and "recently killed" trees had lost all foliage during the disturbance and either failed to resprout or all resprouts were dead. 


\subsection{Data Analysis}

\subsubsection{Damage and Tissue Moisture}

Since stem damage and tissue moisture were found to be similar between E. marginata and C. calophylla following Mann-Whitney tests (damage $U=2.39$, $\mathrm{df}=1, p=0.1217$, moisture $U=0.81$, df $=1, p=0.3679$ ), they were grouped for all analyses. To examine the association between $P$. semipunctata damage and crown health class, the proportion of inner bark damaged (severity) by P. semipunctata and tissue moisture were analyzed using nonparametric Kruskal-Wallis tests followed by Mann-Whitney tests with Bonferonni correction in SAS (Statistical Analysis System, SAS Institute, version 9.3, Cary, NC, USA) due to non-normally distributed data. Means $( \pm$ SE) are shown as appropriate. To determine whether inner bark damage (\%) is related to tissue moisture (\%), Spearman Rank correlation procedure (PROC CORR) was used in SAS.

\subsubsection{Infestation Levels}

We compared E. marginata and C. calophylla infestation levels using Mann-Whitney tests and were found to be not significantly $(U=1.07$, $\mathrm{df}=1, p=0.285)$ different. Data were then pooled for all analysis. To compare infestation levels of $P$. semipunctata in severely and minimally drought-affected forest areas and the percentage of trees and infestations of $P$. semipunctata among each crown health class in the severely-affected forest area were analyzed using nonparametric Kruskal-Wallis tests followed by Mann-Whitney tests with Bonferonni correction due to unequal variances among health classes in Genstat v16 for Windows, (VSN International, Hempstead, United Kingdom). Means $( \pm$ SE) are shown as appropriate.

\section{Results}

\subsection{Damage and Tissue Moisture}

Phoracantha semipunctata damage to the inner bark/phloem was found to vary with crown condition $\left(H_{2}=37.97\right.$, df $\left.=2, P<0.0001\right)$, with the greatest damage in trees considered to be recently-killed when surveyed (Figure 2). There was a significant negative relationship $(r=-0.4009$, $p<0.0001$ ) between tissue moisture and the proportion of inner bark damaged (Figure 3 ). 


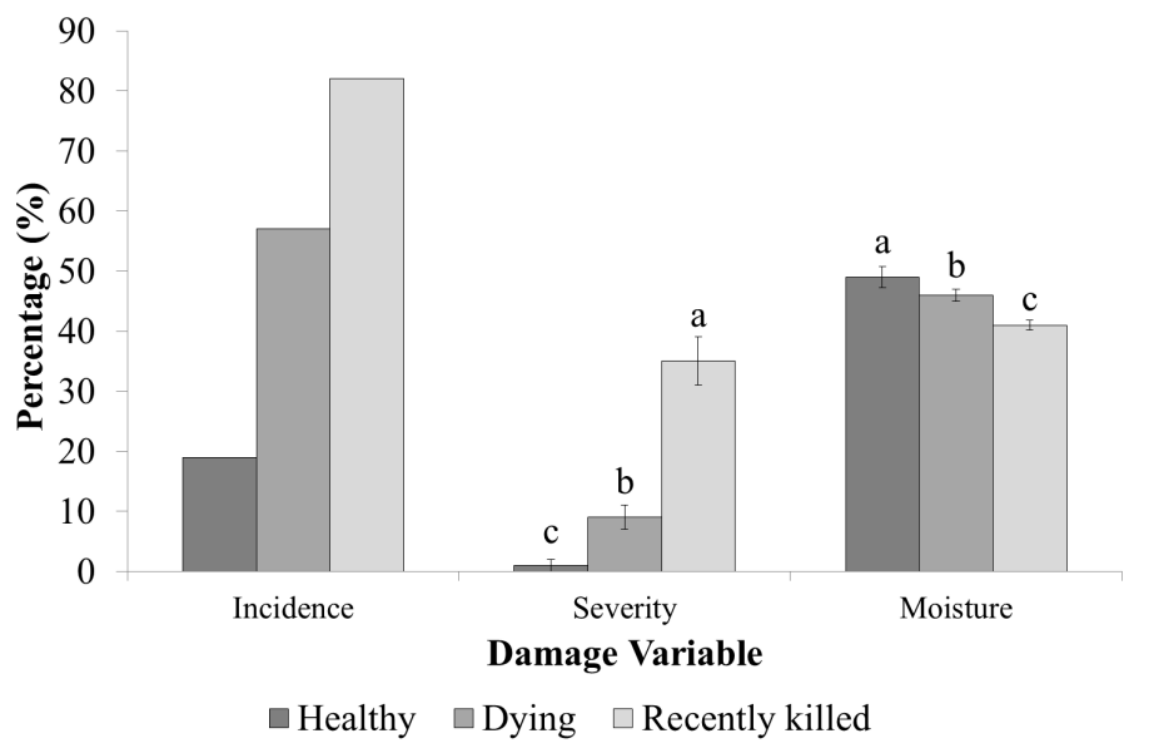

Figure 2. The pooled percentage incidence of Phoracantha semipunctata damage, the average severity of damage (\% inner bark surface area damaged) and mean tissue moisture content $(\%)$ in healthy, dying and recently killed trees across 20 sites in the Northern Jarrah Forest, southwestern Australia $(n=60)$. Significant differences among crown health classes were found for damage severity and tissue moisture from Kruskal-Wallis tests at alpha $=0.05$. Columns sharing the same letter within a variable are not different from individual Mann-Whitney tests with Bonferroni correction. Error bars represent the standard error of the mean.

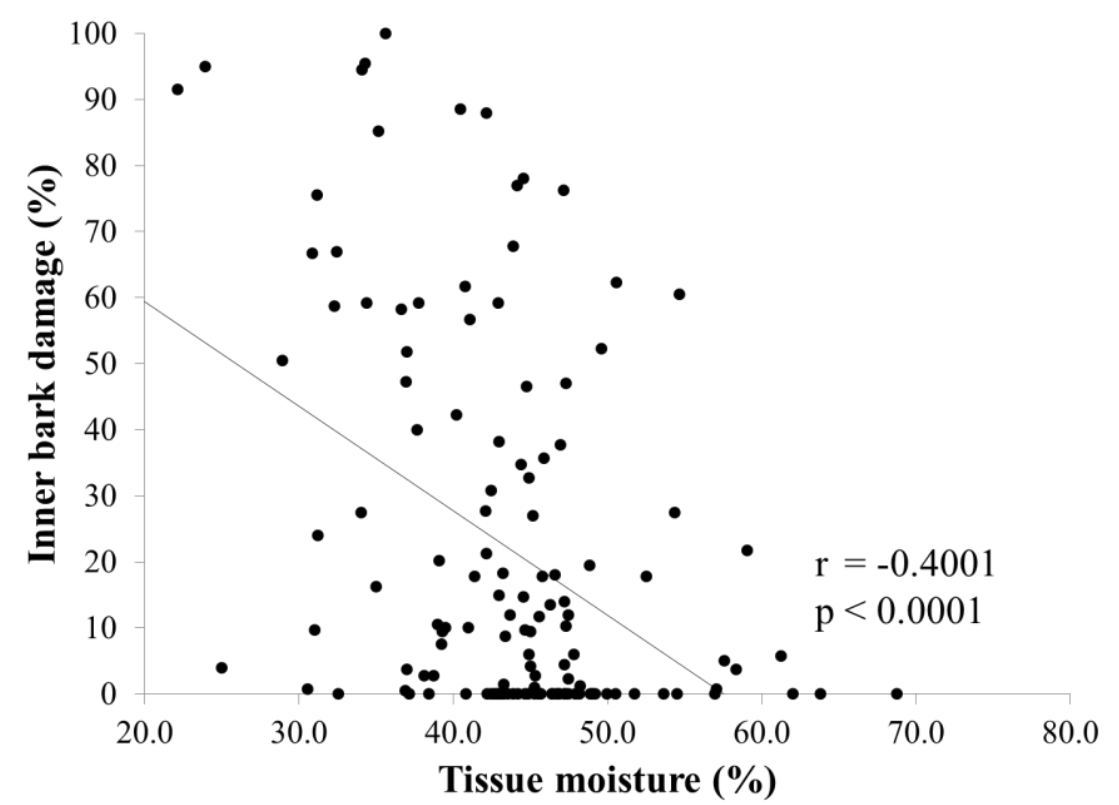

Figure 3. Correlation between the percentage tissue moisture and the percentage of inner bark damaged from Phoracantha semipunctata in the Northern Jarrah Forest, southwestern Australia. A significant relationship was determined from Spearman Rank correlation at alpha $=0.05$. 


\subsection{Infestation Levels}

On average in the severely-affected forest area, $P$. semipunctata infestation levels (measured as exit holes) were 80 times higher than in the minimally-affected area $\left(3.44 \pm 0.39 \mathrm{~m}^{-2} v s .0 .05 \pm 0.04 \mathrm{~m}^{-2}\right.$, $H=60.85$, df $=1, P<0.001$ ) (Figure 4). This scaled-up to an estimated 2265 beetles per hectare for a severely-affected forest and 41 beetles per hectare for a minimally-affected forest, when considering only the lower $2 \mathrm{~m}$ of trees.

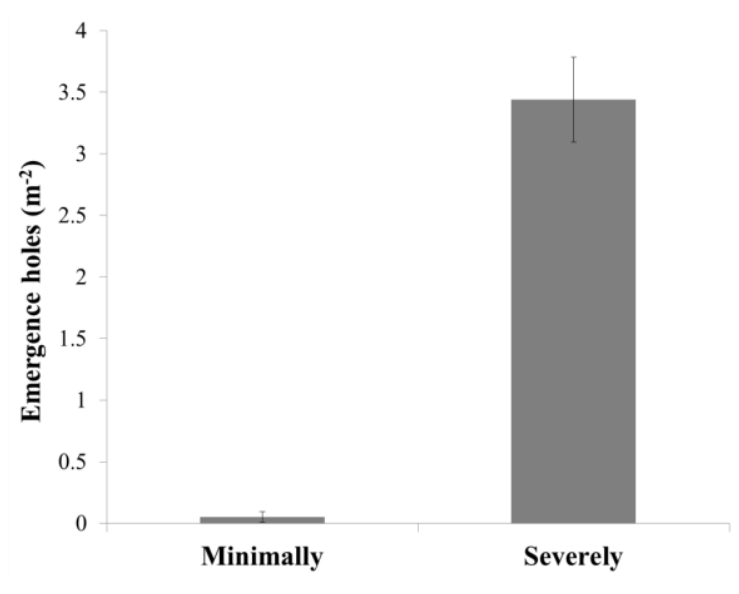

Figure 4. Mean density of Phoracantha semipunctata emergence holes $\left(\mathrm{m}^{-2}\right)$ per bottom $2 \mathrm{~m}$ of stems in minimally and severely drought-affected forest areas in Northern Jarrah Forest, southwestern Australia. Significant differences between forest areas were found for emergence holes from Kruskal-Wallis tests at alpha $=0.05$. Error bars represent the standard error of the mean, $n=92,304$.

In the severely-affected forest, the majority of trees showed severe dieback $(>50 \%)(H=21.33$, $\mathrm{df}=3, P<0.001$ ) with the highest incidence of trees being infested by $P$. semipunctata (Figure 5).

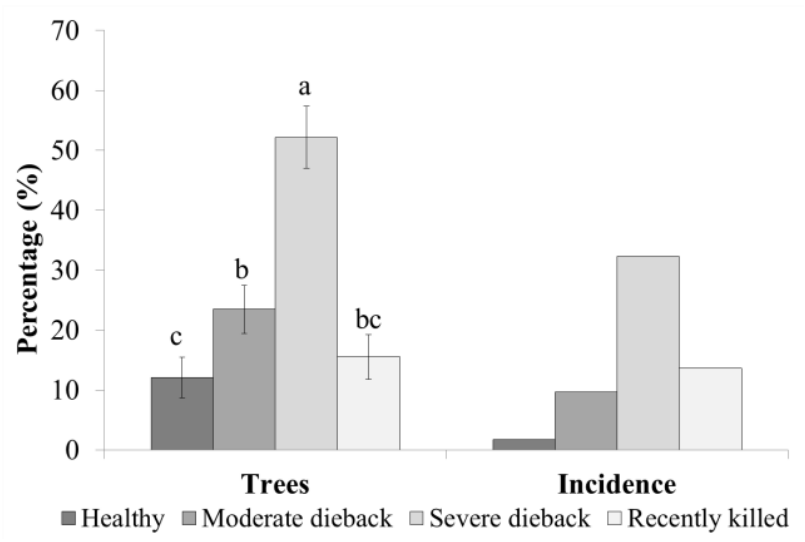

Figure 5. The mean percentage of trees and the pooled percentage incidence of Phoracantha semipunctata emergence holes in trees from four crown health classes within the severely drought-affected forest area across 11 sites in the Northern Jarrah Forest, southwestern Australia. Significant differences among trees with different health classes were found from Kruskal-Wallis tests at alpha $=0.05$. Columns sharing the same letter for 
percentage trees are not different from Mann-Whitney tests with Bonferroni correction.

Error bars represent the standard error of the mean.

Density of $P$. semipunctata emergence holes varied with crown health class $(H=21.26$, df $=3$, $P<0.001$ ), where infestation levels increased as crown health deteriorated (Figure 6). Emergence holes in trees with severe dieback and recently killed were 17 times higher compared to trees that were healthy or had moderate dieback (Figure 6). Density of $P$. semipunctata emergence holes was found to be different between sites $(H=37.22$, df $=10, P<0.001)$.

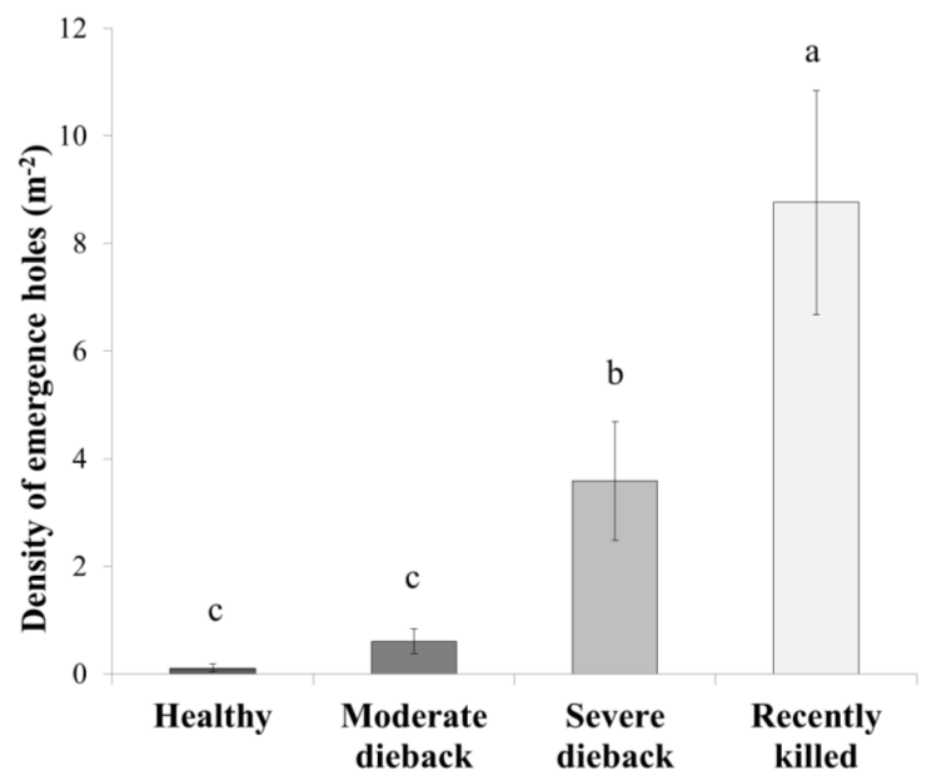

Figure 6. The density of emergence holes $\left(\mathrm{m}^{-2}\right)$ of Phoracantha semipunctata in trees with different crown health classes within severely-affected forest areas across 11 sites in the Northern Jarrah Forest, southwestern Australia. Significant differences between emergence holes in trees with health classes were found from Kruskal-Wallis tests at alpha $=0.05$. Columns sharing the same letter are not different from individual Mann-Whitney tests with Bonferroni correction. Error bars represent the standard error of the mean.

\section{Discussion}

This is the first study to report that, following a severe drought, canopy collapse was one of the main contributors to outbreaks of $P$. semipunctata, in a native ecosystem in Australia. While this interaction is well known in California and other regions where $P$. semipunctata and its hosts have been introduced, it has been rarely reported from native ecosystems [19]. These findings are significant since the tree species in the Northern Jarrah Forest have historically been resistant to the combined effects of drought and forest pests [37]. This beetle outbreak, along with other pest outbreaks in similar ecosystems [23], suggest that climate shifts are changing host-pest interactions in the region.

Host defense against forest pests is expected to be altered with climate change and associated increases in host stress [12]. Inner bark tissue moisture has been found to be an important defense against the successful development of $P$. semipunctata in eucalypts [14,34]. Sufficient inner bark and phloem moisture is thought to force larvae to feed in poorer quality outer bark tissue, which can reduce 
beetle growth and survival and limit damage to the host [14]. If beetles are unable to avoid the moist inner bark, death of larvae can occur from excessive moisture, or drowning [34]. The association between low tissue moisture and high inner bark damage reported here, during severe drought, provides some support for previous findings [14,34]. However, other related factors, including the concentration of non-structural carbohydrates in tissues, reduced secondary defense compounds, and elevated temperatures may have also contributed to larval development [38-40]. Further research is necessary to determine the environmental changes that occur in hosts during periods of drought stress, and the relative influence of these factors on $P$. semipunctata establishment and success in the Northern Jarrah Forest.

This is the first study to estimate population levels of $P$. semipunctata in the Northern Jarrah Forest, and indeed any natural forest in its native range. Infestation levels of $P$. semipunctata observed in minimally-affected forest are likely to be near, background levels for the Northern Jarrah Forest, since the level of drought stress observed in these areas is consistent with that observed during the seasonal summer drought. In comparison, background levels of other endemic Cerambycids, such as E. rufulus are generally higher [13]. However, outbreak population levels of $P$. semipunctata were found to be comparable to levels of E. rufulus in oak (Quercus spp.) trees [35]. The implications of high populations of $P$. semipunctata are not well-known in its native ecosystems; however, this study clearly shows that beetles stayed confined to severely-stressed areas, unlike the pine bark beetles in North America's forests which attacked healthy trees during outbreaks [41]. This suggests that populations of $P$. semipunctata fall considerably after the cessation of drought. Despite this, with continued drying in southwestern Australia, the combination of drought and heat may lead to more frequent and severe outbreaks of $P$. semipunctata.

The drought-induced canopy collapse in the Northern Jarrah Forest was not unlike other mortality events observed in recent years [42], in terms of its severity and extent. While results from this study strongly suggests $P$. semipunctata populations are likely to rise in the coming years with increases in forest drought stress, the effects of increased beetle populations on the Northern Jarrah Forest is unclear. If the behavior of P. semipunctata in the Northern Jarrah Forest closely follows that of other endemic Cerambycids [35,43], population outbreaks such as the one observed following the 2011 collapse may predispose trees to suffer higher mortality during less severe drought episodes in future years. Increased population monitoring may enable us to determine the magnitude of forest changes from $P$. semipunctata outbreaks in relation to climate warming.

\section{Conclusions}

Drought-affected trees in this study were vulnerable to beetle attack from the native Cerambycid, $P$. semipunctata, with trees killed by the 2011 drought containing the highest infestation levels. Low levels of tissue moisture in dead and dying trees, which is known to make other hosts susceptible to $P$. semipunctata, was correlated with high levels of beetle damage. Since P. semipunctata was largely restricted to trees severely-affected by drought, and these trees were concentrated in discrete areas, there is minimal evidence that $P$. semipunctata can attack and kill trees not experiencing severe water stress. However, as a result of climate change, drought prone areas are expected to become more common and could result in more frequent outbreaks. 


\section{Acknowledgments}

The authors thank Department of Parks and Wildlife for their support in accessing the Northern Jarrah Forest. Financial support for this research was provided in part through a National Climate Change Adaptation Research Facility (NCCARF) grant and Murdoch University.

\section{Author Contributions}

Stephen Seaton designed the original study, undertook fieldwork and running of the experiment, analyzed data and co-wrote the manuscript. George Matusick assisted with design and fieldwork, analyzed data and co-wrote the manuscript. Katinka Ruthrof assisted with design and fieldwork and co-wrote the manuscript. Giles E. St. J. Hardy assisted with designing the experiment and carried out manuscript editing.

\section{Conflicts of Interest}

The authors declare no conflict of interest.

\section{References}

1. Negrón, J.F.; McMillin, J.D.; Anhold, J.A.; Coulson, D. Bark beetle-caused mortality in a drought-affected ponderosa pine landscape in Arizona, USA. For. Ecol. Manag. 2009, 257, 1353-1362.

2. Hart, C.J. Drought induces spruce beetle outbreaks across northwestern Colorado. Integr. Pest Manag. Rev. 2014, 6, 247-252.

3. Knight, S.K.; Brown, J.P.; Long, R.P. Factors affecting the survival of ash (Fraxinus spp.) trees infested by emerald ash borer (agrilus planipennis). Biol. Invasions 2013, 15, 371-383.

4. Intergovernmental Panel on Climate Change. Climate Change 2014: The Physical Science Basis. Contribution of Working Group I to the Fifth Assessment Report of the Intergovernmental Panel on Climate Change; Cambridge University Press: New York, NY, USA, 2014.

5. Bentz, B.J.; Régnière, J.; Fettig, C.J.; Hansen, E.M.; Hayes, J.L.; Hicke, J.A.; Kelsey, R.G.; Negrón, J.F.; Seybold, S.J. Climate change and bark beetles of the western United States and Canada: Direct and indirect effects. BioScience 2010, 60, 602-613.

6. Diffenbaugh, N.S.; Pal, J.S.; Giorgi, F.; Gao, X. Heat stress intensification in the Mediterranean climate change hotspot. Geophys. Res. Lett. 2007, 34, L11706.

7. Bates, B.C.; Hope, P.; Ryan, B.; Smith, I.; Charles, S. Key findings from the indian ocean climate initiative and their impact on policy development in Australia. Clim. Chang. 2008, 89, 339-354.

8. Peñuelas, J.; Lloret, F.; Montoya, R. Severe drought effects on Mediterranean woody flora in Spain. For. Sci. 2001, 47, 214-219.

9. Coulson, R.N.; Stephen, F.M. Impacts of insects in forest landscapes-implications for forest health management. In Invasive Forest Insects, Introduced Forest Trees, and Altered Ecosystems; Paine, T.D., Ed.; Springer: Dordrecht, The Netherlands, 2006; pp. 101-125. 
10. Hebertson, E.G.; Jenkins, M.J. Climate factors associated with historic spruce beetle (coleoptera: Curculionidae) outbreaks in Utah and Colorado. Environ. Entomol. 2008, 37, 281-292.

11. Boucher, T.V.; Mead, B.R. Vegetation change and forest regeneration on the Kenai Peninsula, Alaska following a spruce beetle outbreak, 1987-2000. For. Ecol. Manag. 2006, 227, 233-246.

12. Flower, C.E.; Gonzalez-Meler, M.A. Responses of temperate forest productivity to insect and pathogen disturbances. Annu. Rev. Plant Biol. 2015, 66, 547-569.

13. Stephen, F.M.; Salisbury, V.B.; Oliveira, F.L. Red oak borer, enaphalodes rufulus (coleoptera: Cerambycidae), in the Ozark mountains of Arkansas, USA: An unexpected and remarkable forest disturbance. Integr. Pest Manag. Rev. 2001, 6, 247-252.

14. Hanks, L.M.; Paine, T.D.; Millar, J.G.; Campbell, C.D.; Schuch, U.K. Water relations of host trees and resistance to the phloem-boring beetle Phoracantha semipunctata F. (Coleoptera: Cerambycidae). Oecologia 1999, 119, 400-407.

15. Duffy, E.A.J. A Monograph of the Immature Stages of Australasian Timber Beetles (Cerambycidae); British Museum (Natural History), Ed.; Trustees of the British Museum: London, UK, 1963; p. 235.

16. Hanks, L.M.; McElfresh, J.S.; Millar, J.G.; Paine, T.D. Phoracantha semipunctata (coleoptera: Cerambycidae), a serious pest of eucalytpus in California: Biology and laboratory-rearing procedures. Ann. Entomol. Soc. Am. 1993, 86, 95-102.

17. Scriven, G.T.; Reeves, E.L.; Luck, R.F. Beetle from Australia threatens eucalyptus. Calif. Agric. 1986, 40, 4-6.

18. Wang, Q. A taxonomic revision of the Australian genus phoracantha newman (coleoptera: Cerambycidae). Invertebr. Taxon. 1995, 9, 865-958.

19. Curry, S.J. The association of insects with eucalypt dieback in south western Australia. In Eucalypt Dieback in Forests and Woodlands; Old, K.M., Kile, G.A., Eds.; CSIRO: Melbourne, Australia, 1981; pp. 130-133.

20. Clarke, J. The marri borer (tryphocaria hamata). J. Agric. West. Aust. 1925, 2, 513-517.

21. Hooper, R.J.; Sivasithamparam, K. Characterization of damage and biotic factors associated with the decline of eucalyptus wandoo in southwest western Australia. Can. J. For. Res. 2005, 35, 2589-2602.

22. Matusick, G.; Ruthrof, K.; Hardy, G. Drought and heat triggers sudden and severe dieback in a dominant Mediterranean-type woodland species. Open J. For. 2012, 2, 183-168.

23. Hooper, R.J.; Wills, A.; Shearer, B.L.; Sivasithamparam, K. A redescription and notes on biology of Cisseis fascigera obenberger (Coleoptera: Buprestidae) on declining eucalyptus wandoo in south-western Australia. Aust. J. Entomol. 2010, 49, 234-244.

24. Matusick, G.; Ruthrof, K.X.; Brouwers, N.C.; Dell, B.; Hardy, G.S.J. Sudden forest canopy collapse corresponding with extreme drought and heat in a Mediterranean-type eucalypt forest in southwestern Australia. Eur. J. For. Res. 2013, 132, 497-510.

25. Hanks, L.M.; Paine, T.D.; Millar, J.G. Influence of the larval environment on performance and adult body size of the wood-boring beetle Phoracantha semipunctata. Entomol. Exp. Appl. 2005, $114,25-34$. 
26. Gentilli, J. Climate of the jarrah forest. In The Jarrah Forest: A Complex Mediterranean Ecosystem; Dell, B., Havel, J., Eds.; Kluwer Academic Publ: Dordrecht, The Netherlands, 1989; pp. 23-40.

27. Marchant, N.G. Species diversity in the southwestern flora. J. R. Soc. West. Aust. 1973, 56, 23.

28. McArthur, W.M.; Churchwood, H.M.; Hick, P.T. Landform and Soils of the Murray River Catchment Area of Western Australia, 3rd ed.; Management, D.O.L.R., Ed.; Commonwealth Scientific and Industrial Research Organization, Division of Land Resources Management: Melbourne, Australia, 1977; pp. 1-23.

29. Brouwers, N.; Matusick, G.; Ruthrof, K.; Lyons, T.; Hardy, G. Landscape-scale assessment of tree crown dieback following extreme drought and heat in a Mediterranean eucalypt forest ecosystem. Land. Ecol. 2013, 28, 69-80.

30. Paine, T.D.; Dreistadt, S.H.; Millar, J.G. Eucalyptus Longhorned Borers; UC Statewide Integrated Pest Management Program, University of California: Davis, CA, USA, 2009.

31. Mitchell, K. Quantitative Analysis by the Point-Centered Quarter Method; Department of Mathematics and Computer Science: Geneva, Switzerland, 2007; pp. 1-37.

32. Flower, C.E.; Knight, K.S.; Rebbeck, J.; Gonzalez-Meler, M.A. The relationship between emerald ash borer (agrilus planipennis fairmaire) and ash (fraxinus spp.) tree decline: Using visual ash condition assessments and leaf isotope measurements to assess pest damage. For. Ecol. Manag. 2013, 303, 143-147.

33. Worrall, J.J.; Egeland, L.; Eager, T.; Mask, R.A.; Johnson, E.W.; Kemp, P.A.; Shepperd, W.D. Rapid mortality of populus tremuloides in southwestern Colorado, USA. For. Ecol. Manag. 2008, 255, 686-696.

34. Hanks, L.M.; Paine, T.D.; Millar, J.G. Mechanisms of resistance in eucalyptus against larvae of the eucalyptus longhorned borer (coleoptera: Cerambycidae). Environ. Entomol. 1991, 20, 1583-1588.

35. Fierke, M.K.; Kelley, M.B.; Stephen, F.M. Site and stand variables influencing red oak borer, enaphalodes rufulus (coleoptera: Cerambycidae), population densities and tree mortality. For. Ecol. Manag. 2007, 247, 227-236.

36. Timms, L.L.; Smith, S.M.; de Groot, P. Patterns in the within-tree distribution of the emerald ash borer (agrilus planipennis fairmaire) in young, green-ash plantations of south-western Ontario, Canada. Agric. For. Entomol. 2008, 8, 313-321.

37. Abott, I.; Loneragan, O. Ecology of Jarrah (Eucalyptus Marginata) in the Northern Jarrah Forest of Western Australia; Department of Conservation and Land Management: Perth, Australia, 1986.

38. Huberty, A.F.; Denno, R.F. Plant water stress and its consequences for herbivorous insects: A new synthesis. Ecology 2004, 85, 1383-1398.

39. Salle, A.; Nageleisen, L.-M.; Lieutier, F. Bark and wood boring insects involved in oak declines in Europe: Current knowledge and future prospects in a context of climate change. For. Ecol. Manag. 2014, 328, 79-93.

40. Koricheva, J.; Larsson, S.; Haukioja, E. Insect performance on experimentally stressed woody plants: A meta-analysis. Ann. Rev. Entomol. 1998, 43, 195-216. 
41. Raffa, K.F.; Aukema, B.H.; Bentz, B.J.; Carroll, A.L.; Hicke, J.A.; Turner, M.G.; Romme, W.H. Cross-scale drivers of natural disturbances prone to anthropogenic amplification: The dynmaics of bark beetle eruptions. BioScience 2008, 58, 501-517.

42. Allen, C.D.; Macalady, A.K.; Chenchouni, H.; Bachelet, D.; McDowell, N.; Vennetier, M.; Kitzberger, T.; Rigling, A.; Breshears, D.D.; Hogg, E.H.; et al. A global overview of drought and heat-induced tree mortality reveals emerging climate change risks for forests. For. Ecol. Manag. 2010, 259, 660-684.

43. Fan, Z.; Kabrick, J.M.; Spetich, M.A.; Shifley, S.R.; Jensen, R.G. Oak mortality associated with crown dieback and oak borer attack in the ozark highlands. For. Ecol. Manag. 2008, 255, 2297-2305.

(C) 2015 by the authors; licensee MDPI, Basel, Switzerland. This article is an open access article distributed under the terms and conditions of the Creative Commons Attribution license (http://creativecommons.org/licenses/by/4.0/). 